\title{
Supplying System for Drinking Water to Small Rural Communities with Zero Greenhouse Gasses: Sixteen Years of Experiences in Mexico
}

\author{
Martín Mundo-Molina ${ }^{1,2}$ \\ ${ }^{1}$ Investigation Centre, Faculty of Engineer, Autonomous University of Chiapas, Tuxtla Gutiérrez, Mexico \\ ${ }^{2}$ Investigation Centre, CIDESTA, Tuxtla Gutiérrez, México \\ Email:ic_ingenieros@yahoo.com.mx,cidestachi@yahoo.com.mx
}

How to cite this paper: Mundo-Molina, M. (2016) Supplying System for Drinking Water to Small Rural Communities with Zero Greenhouse Gasses: Sixteen Years of Experiences in Mexico. Journal of Water Resource and Protection, 8, 1044-1052. http://dx.doi.org/10.4236/jwarp.2016.812083

Received: June 7, 2016

Accepted: October 30, 2016

Published: November 2, 2016

Copyright $\odot 2016$ by author and Scientific Research Publishing Inc. This work is licensed under the Creative Commons Attribution International License (CC BY 4.0).

http://creativecommons.org/licenses/by/4.0/ (c) (i) Open Access

\begin{abstract}
In Chiapas highlands to southeast of Mexico, the scarcity of water is worrying, according to technical reports of the IPCC the runoff will less between 150 to $250 \mathrm{~mm}$ per year in the southeast of Mexico, this situation will increase the problems of water availability in Chiapas highlands in the future. For actually more of 18,160 small rural indigenous communities (SRIC) in Chiapas there is not drinking water. In order to contribute a given solution to scarcity of drinking water in the SRIC, The Autonomous University of Chiapas (UNACH in its Spanish acronym) and Mexican Institute of Water Technology (IMTA in its Spanish acronym) designed and constructed in 1999 the Rain Water Harvesting (RWH) in Yalentay municipality of Zinacantan in Chiapas, Mexico. The scientific and technical contributions of RWH are: The design guarantee the water quality for a prolonged time of storage avoiding the photosynthesis inside the system; Not emitted greenhouse gasses because it doesn't need any kind of fossil fuels; Not produces anything kind of damage to the environment; It has to be inexpensive, using in its construction manpower and materials from de region; Store the maximum quantity of water in the minimum space. The RWH has increased the standard of living of the habitants from Yalentay and improving their health conditions.
\end{abstract}

\section{Keywords}

Climatic Change, Rain Water Harsvesting, Technology Appropiatte, Greenhouse Gasses

\section{Introduction}

The indigenous communities in Mexico live in precarious conditions in matter of 
education, living, and basic health services. Thousands of them lack, even the most basic things, for example, dispose of drinking water. In 1995 it was calculated that the 803 municipalities with more than $70 \%$ of indigenous population, the $44 \%$ was debated in life conditions catalogued as highly marginalized [1] [2]. With a population a little more 10,000,000 of people distributed around the national territory [3], the indigenous communities from México, live since hundreds of years in unhealthy conditions, with lack of basic infrastructure to live with dignity, thousands of them in extreme poverty and with exterior communication issues, because in México are spoken more than 72 native languages different from Spanish, this represents a difficulty, specially for adults, regarding communication and citizen rights. The indigenous population of México is concentrated principally in the center and south states from México. The states with more indigenous population in México are Oaxaca, with more than a 1,000,000 and a half of people; Chiapas, also with more than a 1,000,000 and a half of habitants; Veracruz, Yucatán, Estado de México y Puebla, with about 900,000 each one. The Hidalgo, Guerrero, Quintana Roo, San Luis Potosí and Tabasco states, also count with a large indigenous population. Distrito Federal lives 333,000 indigenous people, turning the city into the urban concentration with the biggest number of indigenous people in México [4].

The water supply for domestic uses and human consume with quality (basic right of every person) is still a utopia in thousands of rural indigenous communities in Mexico. They are living in extreme poor conditions. In relation to the level of poverty, a performed study in 1994 in four Latin-American countries (Bolivia, Guatemala, México and Peru) showed that in México $81 \%$ of the indigenous lived down from the line of poverty, income less than two dollars per day [5].

According to official estimates, the $42 \%$ of the indigenous dwelling in México lacked of piped water in the year 2000 and the $70 \%$ lacked of sanitation services. This explains part of the resurgence of deceases like cholera and the persistence of typhus in those regions [4]. México keeps recording, particularly in the rural zones, the high indices of infectious deceases which transmission is associated to the lack of water or the consume of contaminated water, for example, in the case of the diarrhea the Ministry of Health informed that this disease is one of the principal causes of death in the indigenous groups, with a rate three times higher than the national [6]. The circumstances set out above in addition to the potential effects of climate change and deforestation could lead to greater water shortages in the highlands of Chiapas. According to technical reports of the IPCC indicates in the southeast of Mexico the watershed runoff will decrease between 150 to $250 \mathrm{~mm}$ per year [7]. Moreover, the average annual deforestation in Mexico is 400,000 ha with 750,000 ha/year as maximum [8] [9].

Under the precariousness conditions of poverty and under the politic circumstances of that time, the Zapatista Indigenous uprising on 1994 was raised in Chiapas, which exteriorized claims were focused on the defense of the individual and collective rights historically denied to the Mexican indigenous villages and the construction of a new nation model that included democracy, freedom and justice as principles of a new form of doing politics. In this claim it was expressed in a veiled form the vindication of 
dignifying the indigenous society trough the public services that every Mexican citizen has the right to enjoy. Under this context trough the IMTA and the Food Agricultural Organization (FAO) in 1995 a technical committee was organized, who traveled to Chiapas in order to analyze the problems in the indigenous communities in relation to the supply of drinking water. The first meeting took place on the Faculty of Engineering of Autonomous University of Chiapas with an international, national and regional group of experts who analyzed the problems related to the water and the indigenous communities. This meeting gave as a result a small investigation group that gave birth to a work line in the IMTA about "Alternative Technologies in Hydraulic" whose first product was the edition of a book called "Manual for the selection of alternative technologies in hydraulic" that IMTA published on 1997 [10].

Starting of the ideas proposed in the book published in 1997 it was born the first research project that tried to analyze the possibility to collect the fog water in order to drinking water supply to small rural communities in Chiapas Highlands through fog collectors, concluding that due to the little water of the fog banks and because of the short duration of the events, it wasn't possible in practice. This technology was taken to a small fisherman community in Punta Baja, Baja California México, where the fog collectors were working for a period of time. The average of water collected in Punta Baja exceeded the volumes collected at Chiapas. While in Chiapas was continued with the search of alternatives to supply drinking water to small indigenous communities under the already described conditions. In these search and based on the Manual for the selection of alternative technologies in hydraulic that the IMTA published in 1997 it was designed the RWH that is presented in this paper, that under a tripartite agreement between IMTA, the International Agency Spanish Cooperation and the Faculty of Engineering of the Autonomous University of Chiapas.

\section{The Water Issue in Indigenous Communities in Chiapas Highlands}

According to the National Institute of Geography Statistics and Informatics [11] there exist in Mexico 192,244 localities which 3653 are urban and 188,591 are rural localities, the last ones with an approximated population of 26,062,076 habitants. In Table 1 are shown the number of rural localities that exist in México and the number of habitants of each one.

Table 1. Number of urban and rural communities in México [11].

\begin{tabular}{ccccc}
\hline \multirow{2}{*}{ Locality size } & \multicolumn{2}{c}{ Mexico } & \multicolumn{2}{c}{ Chiapas } \\
\cline { 2 - 5 } & Localities & Population & Localities & Population \\
\hline Total habitants & 192,244 & $112,336,538$ & 20,047 & $4,796,580$ \\
From 1 to 2499 & 188,591 & $26,062,077$ & 19,867 & $2,460,645$ \\
From 2500 to 14,999 & 3076 & $16,064,125$ & 140 & 748,266 \\
From 15,000 to 49,999 & 384 & $10,559,634$ & 20 & 594,776 \\
\hline
\end{tabular}


INEGI informed [11] that Mexico has 112,336,530 inhabitants, the $10 \%$ are indigenous people. The SRIC are concentrated in the south of México. Thus, Chiapas is one of the provinces from México with the highest indigenous population rates in the country. Only in Chiapas there are 19,867 small rural communities with less than 2500 habitants of which 18,160 communities there are less than 500 habitants, the vast majority has health issues that are mostly related to the bad water quality or the lack of it. These communities are located in hard to reach areas by their remoteness or topography, located in mountainous areas, far from important population centers and a high dispersion of the dwellings. The vast majority of SRIC is located in Chiapas Highlands where is lacking of supply sources like rivers, creeks or water springs, reason why the conventional ways for water endowment is not possible, whether for economic or technical reasons. According to the official data of [12] in Chiapas there is a total cover of drinking water of $89.9 \%$ and a cover of wastewater treatment of $47.2 \%$, while other sources indicate that $41 \%$ of the population lacks of piped water and $55.7 \%$ lacks of sanitary sewerage. Thus, it appears to be more coincident with reality the unofficial numbers, because as it has been enunciated, Chiapas rural population represents almost 50\% of the total state population and the vast majority of it lacks of drinking water supply services. These rates are a consequence (among other causes) of a large dispersion of the small rural communities and mountainous topography of Chiapas. Providing drinking water in some zones from Chiapas by conventional ways results expensive, and in most of the cases impossible. An alternative for drinking water supply to the SRIC and lots of other regions of the country is the RWH which technical description, basic design elements and constructive process is shown below.

\section{The Rain Water Harvesting in Yalentay, Chiapas Mexico}

\section{Technical description}

The RWH roof's is galvanized sheet supported by wooden beams (Figure 1). The

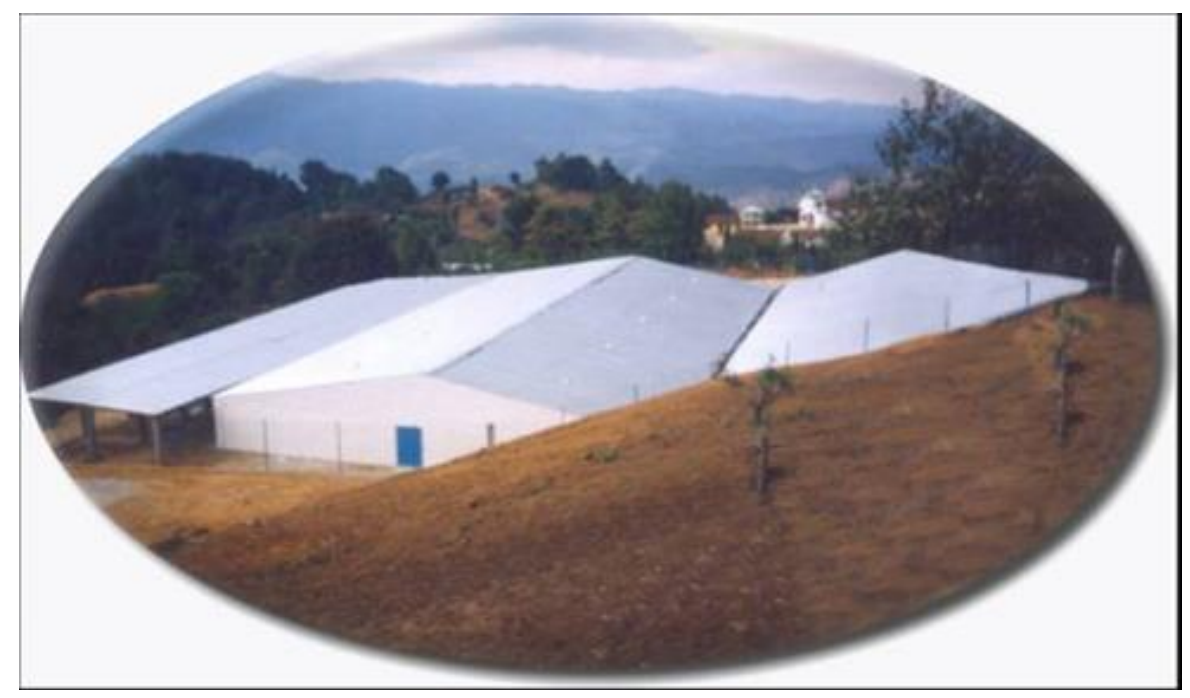

Figure 1. Rainwater harvesting in Yalentay Chiapas, Mexico. 
storage tank with great capacity (STGC) has a pyramidal geometry, truncated and inverted. The natural walls of inverted pyramid were covered with concrete over metal mesh, in order to give rigidity to it. The rainwater collected by the roof is transported by artificial channels to STGC. The STGC is divided is two deposits, crossed in its longitudinal section by a pedestrian bridge to facilitate maintenance [13]. The RWH has two kind of natural filters: quickly and slow, both made with layers of sand, coal and gravel. The quickly filter capture the water directly from the collector roof and drive it to the STGC. The slow filter receives the water from the STGC and drives it to distribution tank (which only stores the total volume of the day). Finally, the water is transported from de distribution tank to the centre of community where there are five taps for supplying water to the population.

To avoid the photosynthesis in the STGC, it is in complete darkness to prevent the proliferation of algae and mosquitoes. The RWH has an aeration system to oxygenate the water, with $U$-shaped tubes in the side of the prevailing wind. It also possesses an eliminator of volume excess (weirs), through a series of tubes placed on the top level of storage tank. The walls that support the collector roof are constructed with a special material named in spanish "tabicón" (tabicón is a rectangular structure made with sand mixed with low resistance concrete). In one of these walls it was constructed a door to access the RWH trough a footbridge. The construction process of the STGC was simple, it began with the excavation of the storage tank, once excavated it continued with the alignment of the walls and then the floor was compressed. Once the compaction was finished the metal mesh was placed on the walls of the storage tank, ending with a flattened with a concrete mix low resistance. And then the walls were built, continuing with the construction of the roof structure, it was placed the ventilation system and the entrance door. The RWH that is currently operating in Yalentay Chiapas Mexico is shown in Figure 1.

\section{Design}

To build a RWH as described in here is necessary to consider the following studies: topographic, soil mechanics, hydrology studies, hydraulics studies, structural design, construction aspects and social study. The social study considered the local culture, for example: Community decisions about the project, religion aspects, relationship between community with Water God, Earth, Environment and Natural Resources. The social methodology was necessary in order to transfer the RWC to indigenous community of Yalentay [14]. The topography provided information about the terrain and their profiles in order to calculate areas and volume about RWH. The topography permits to make the preliminary design of roof, channels, walls, storage tanks, filters and pipes from RWH to facility its construction. The studies of soil mechanics allow to have two basic data: resistance of soil in order to design the structural basements that will support columns and the roof structure, and soil type will allow knowing the infiltration capacity in the ground. In some cases there will be the need for a test using an infiltrometer device, to know the rate of infiltration of the soil under study for deciding improve the soil in order to reduce the soil infiltration capacity. If the infiltration rate 
exceeds the allowed limit, the base of the storage tank will be covered with a polypropylene plastic. The hydrological study is essential to know the intensity of rainfall in the region for calculating the minimum area of the roof collector. Rain intensities associated with several return periods will enable doing a good design of the system channels, the capacity and size of the RWH filters, so that the construction of the IDT hydrologic curves are necessary. Average annual normalized rainfall $(\bar{P})$ is used to size the storage tank volume is a function of daily demand $(D)$ and storage time $(t)$. Here is gave the main hydraulics variables in order to make an adequate design of RWH. Thus, the volume demand for population is obtained from the equation of conservation of mass in its kinetic version:

$$
\frac{d Q}{d t}=\frac{d}{d t}(v A)
$$

Thus, using the mass conservation equation in volumetric form, the maximum volume of RWH is:

$$
\frac{d}{d t}\left(\frac{v}{t}\right)=\frac{d Q}{d t}
$$

The rate of change of volume is a function that depends on the flow and time:

$$
\frac{d V}{d t}=\left(\frac{d Q}{d t}\right)(t)
$$

If $Q$ can be written as:

$$
Q=f[(D)(P)]
$$

Then:

$$
\frac{d V}{d t}=(D) \frac{d}{d t}(P)(t)
$$

Integrating Equation (5) is obtained:

$$
V=(D)(P)(t)
$$

Equation (6) determines the maximum volume design of RWH.

If:

$$
\frac{d V}{d t}=A \frac{d \bar{P}}{d t}
$$

Equating Equations (5) and (6):

$$
A \frac{d \bar{P}}{d t}=D \frac{d}{d t}(P)(t)
$$

Thus, the maximum area in $\mathrm{m}^{2}$ for roof collector is a mathematical function as:

$$
A=\frac{D \frac{d}{d t}(P)(t)}{d \bar{P}} d t
$$

Considering future changes for effects of climate change it is estimated that some areas of the world will be reductions in rainfall in the order of 18\% [15]. It, according to 
[16] in the case of Chiapas 2020, is expected to precipitation scenarios there is a decline between $-4 \%$ and $-14 \%$ for various regions of the state. Thus the collection surface $(A)$ considering a reduction effect of rain $20 \%$ due to the effects of climate change can be estimated with the next equation:

$$
A=\frac{D \frac{d}{d t}(P)(t)}{(d \bar{P})(0.80)} d t
$$

where:

$Q=$ Flow population demand (1/s)

$t=$ Time $(\mathrm{d})$

$V=$ Average flow velocity $(\mathrm{m} / \mathrm{s})$

$A=$ Hydraulic section $\left(\mathrm{m}^{2}\right)$

$V=$ Total or maximum storage volume of RWH (l)

$D=$ Average daily water usage $(\mathrm{l} / \mathrm{p} \cdot \mathrm{p} / \mathrm{d})$

$P=$ Total number of people to drinking water supply

$\bar{P}=$ Average annual rainfall $(\mathrm{m})$

After obtaining the flows for various return periods with hydrological information, the uniform flow equation [6] for prismatic channels allow to design the dimensions of the channels from RWH. For the case described here, it was considered for the channels with $z=0$ (lateral slope) and longitudinal channels slope (So) less than $1 \%$. Therefore the Manning-Strikler equation allow to calculated the geometric channels dimensions:

$$
R_{h}=\left\lceil\frac{(v)(n)}{\sqrt{S_{o}}}\right\rceil^{\frac{3}{2}}
$$

where:

$$
\begin{aligned}
& V=\text { Average flow velocity in the prismatic channel }\left(\mathrm{ms}^{-1}\right) \\
& n=\text { Manning roughness } \\
& R_{h}=\text { Hydraulic radius }(\mathrm{m}) \\
& S=\text { Longitudinal slope of the prismatic channel }
\end{aligned}
$$

Moreover, in order to support the roof Reed RWH is necessary to design a wooden structure with beams Fink type. Structures or beams Fink will be supported by concrete columns in order to transmit the weight to the ground. If the area is seismic and high wind speeds will be necessary to design under seismic and wind conditions. Finally the social and technology transfer should be considered before construction of RWH and must be executed by a team of experts in sociology, communication and anthropological aspects to ensure the transfer of the system and make users take as their own the project.

\section{Maintenance of RWH}

The RWH maintenance is simple, the next aspects will be consider: 1) Internal cleaning of storage tanks should be done at least once every year, 2) Before the rain season start, the roof, channels and lines pipe should be cleaned, 3) The water in the storage tank can be treated with chlorine, 4) It is recommended that the filter is cleaned 
before the start of the rain season. The maintaining of RWH in Yalentay is done by the community by washing the storage tank and filters in the Water Festival. The Water Festival is a syncretic religious party that the Yalentay community celebrates each April 15 th.

\section{Conclusion}

This paper presented a RWH that is unique in México and Latin-America because of its design, physic characteristics, transfer scheme, and adaptability to the rural communities. Actually the RWH is working since more than sixteen years in the Tzotzil indigenous community of Yalentay in the municipality of Zinacantan, Chiapas Mexico. The RWH transfer was a success because the community made the project of their own. The proof of this is that every April 15th it celebrated the religious festival called "water festival", this is a cultural syncretic manifestation, as a result of the indigenous rites of the past and the Christian rites. The RWH is inexpensive, easy to build and does not pollute the environment, ensuring water supply in rural areas where the average rainfall is adequate for this. Because of its filter natural system, it provides drinking water for human consumption. RWH has generated multiple benefits to the Yalentay community, raising the standard of living, among others: 1) The decrease of diarrheic deceases, 2) The decrease of skin deceases, 3) The kids consume drinking water in school, that came directly from the CALL, 4) There is less school absenteeism because of the reduction in water-related diseases, 5) Women do not have to walk on a rugged topography to get water, often of poor quality. It is an economic system and it requires not conventional energy for this reason not emitted greenhouse gasses because it doesn't need any kind of fossil combustible. The RWH has a high use potential, not only to support the drinking water supply in areas where trachoma is a serious health problem in the Highlands of Chiapas, nut in hundreds of rural communities of the country and Latin-America. These factors and realities made the Yalentay project earn in November 2010 the United Nations and the Government of the United Arab Emirates through the UN-Habitat Global awarded a prize "Dubai Award 2010", in a competition between more than 90 countries of the world. It is suggested to see the following link in Internet https://www.youtube.com/watch?v=bsKjzsSWTpM.

\section{Acknowledgements}

Special thanks to Juan Pablo Mundo-Navarro for reviewing this paper.

\section{References}

[1] INI. (1993) Indicadores socioeconómicos de los pueblos indígenas de México, 1990. Subdirección de Investigación, Instituto Nacional Indigenista (INI). México.

[2] INI. (1999) Información básica sobre los pueblos indígenas de México. Instituto Nacional Indigenista (INI). México.

[3] INEGI. (2000) Censo general de población y vivienda 2000. Instituto Nacional de Geografía e Informática (INEGI). http://www.inegi.org.mx/ 
[4] Peña, F. (2005) La lucha por el agua. Reflexiones para México y América Latina. En P. Dávalos (Comp.), Pueblos indígenas, estado y democracia, CLACSO, Buenos Aires, 217238.

[5] Psacharopoulos, G. and Patrinos, H. (1994) Indigenous People and Poverty in Latin America: An Empirical Analysis. The World Bank, Washington DC.

http://dx.doi.org/10.1596/0-8213-2958-8

[6] SSA-INI (1992) La salud de los pueblos indígenas en México. Secretaría de Salubridad y Asistencia. Instituto Nacional Indigenista, México.

[7] IPCC (2001) Tercer Informe de Evaluación. Cambio climático 2001. Impactos, adaptación y vulnerabilidad. Grupo Intergubernamental de Expertos sobre Cambio Climático. OMM. PNUMA.

[8] Castillo, P.E., Lehtonen, P., Simula, M., Rosa, V. and Escobar, R. (1989) Proyecciones de los principales indicadores forestales de México a largo plazo (1988-2012). Reporte interno. Subsecretaría forestal. Cooperación México-Finlandia. SARH. México.

[9] Masera, O., Ordóñez, M.J. and Dirzo, R. (1992) Emisiones de carbono a partir de la deforestación en México. Ciencia, 43, 151-153.

[10] Mundo-Molina, M., Martínez Austria, P., Hernández Barrios, L. and Delgado Bocanegra, A. (1997) Tecnologías alternativas en Hidráulica. Guía técnica para la selección. Instituto Mexicano de Tecnología del Agua, México.

[11] INEGI (2010) Perspectivas estadísticas Chiapas. Instituto Nacional de Geografía e Informática (INEGI). http://www.inegi.org.mx/

[12] CONAGUA (2009) Situación del subsector agua potable, alcantarillado y saneamiento 2009. Subdirección General de Agua Potable, Drenaje y Saneamiento. Coordinación General de Atención Institucional. Comunicación y Cultura del Agua de la Comisión Nacional del Agua, México, DF.

[13] Mundo-Molina, M., Ballinas, A.R., Martínez, A.P., Hernández, B.L., Ponce, M.M. and Ferrer, P.R. (1998) Colección de agua de lluvia: una alternativa para la dotación de pequeñas comunidades rurales menores de 500 habitantes. Quinta Reunión Nacional sobre Sistemas de Captación de Agua de Lluvia. Oaxaca, México.

[14] Mundo-Molina, M., Martínez, A.P., Ballinas, A.R. and Rodríguez, L.M. (1999) La importancia de las ciencias sociales y de comunicación en la transferencia de tecnología, caso de estudio: construcción de un colector de agua de lluvia en la comunidad indígena Tzotzil de Yalentay, Chiapas. Sexta Reunión Nacional sobre Sistemas de Captación de Agua de Lluvia. Jalapa, Veracruz, México.

[15] Guirado, S.G. and López, B.F. (2011) Tendencia de las precipitaciones y temperaturas en una pequeña cuenca fluvial del sureste peninsular semiárido. Boletín de la Asociación de Geógrafos Españoles No. 56, 349-371.

[16] Ramos, H.S., Morales, I.H., Magaña, R.V., Méndez and Pérez, P.J. (2010) Escenarios climáticos para el estado de Chiapas. Informe final. Centro de Investigación en Gestión de Riesgos y Cambio Climático. Universidad de Ciencias y Artes de Chiapas. 
Submit or recommend next manuscript to SCIRP and we will provide best service for you:

Accepting pre-submission inquiries through Email, Facebook, LinkedIn, Twitter, etc. A wide selection of journals (inclusive of 9 subjects, more than 200 journals)

Providing 24-hour high-quality service

User-friendly online submission system

Fair and swift peer-review system

Efficient typesetting and proofreading procedure

Display of the result of downloads and visits, as well as the number of cited articles

Maximum dissemination of your research work

Submit your manuscript at: http://papersubmission.scirp.org/

Or contact jwarp@scirp.org 